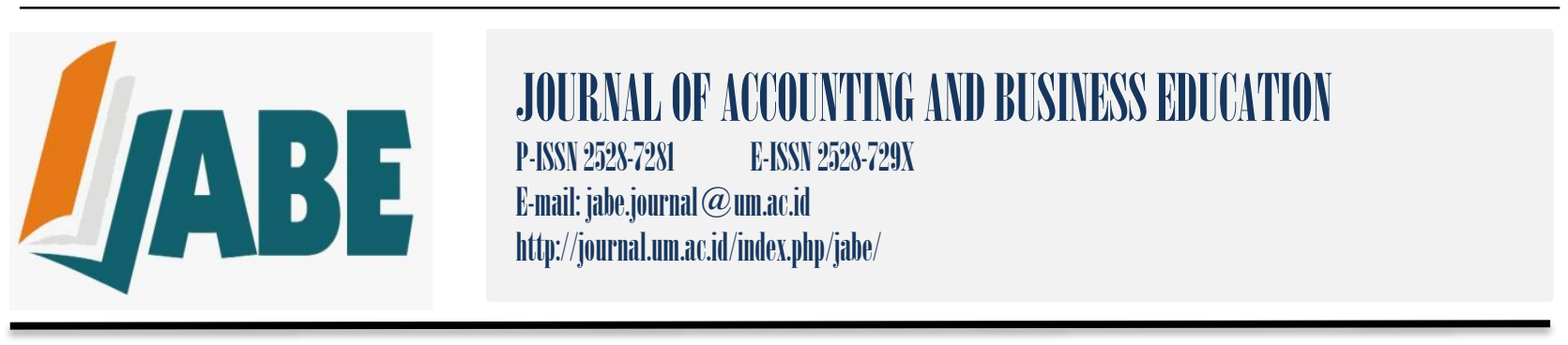

\title{
Credit Risk-Return Puzzle: Asian Countries Representative
}

\author{
Faurani Santi Singagerda \\ Tulus Suryanto \\ Jesscia Christina Sudjana \\ Universitas Sang Bumi Ruwa Jurai \\ IAIN Raden Intan Lampung \\ Universitas Pelita Haapan
}

\begin{abstract}
This research investigates the presence of Credit Risk-Return Puzzle on Indonesia, China, Japan and Singapore, by analyzing the relationship between credit risk and stock return with the utilization of credit ratings from Moody's to represent credit risk. The data comprises of monthly data from January 2001 to December 2015, compiled in an unbalanced panel and then regressed with the Hausman-Taylor Estimator due to the presence of timeinvariant variables such as countries and country classifications within the dataset.

The results from this research show that Credit Risk-Return Puzzle exists in both developed and developing market for long-term credit ratings, proven by the negative relationship between stock return and credit ratings. On the other hand Credit Risk-Return Puzzle does not exist in the case of credit rating changes in terms of direction but do show some signs of existence through difference in magnitude, as different reasons underlying credit rating changes such as leverage changes can change the direction of stock price movement.
\end{abstract}

Keywords: credit risk-return puzzle, credit rating announcements, credit risk, impact of rating changes, decoupling-recoupling hypothesis

\section{INTRODUCTION}

Therotically, firms with high credit risk tend to have a lower return than firms with lower credit risk. (negative relationship). Meanwhile, there is evidence of "distress effect" and it is more pronounced amongst small, illiquid stocks. Avramov, Chordia, Jostova \& Philipov (2009) assess the credit risk-return puzzle and conclude that low credit risk firms realize higher returns than high credit risk firms, which comes out as puzzling because investors are supposed to be paid a premium for bearing extra credit risk. BissoondoyalBheenick \& Brooks (2015) show that low credit quality firms perform poorly after credit rating downgrades announcements, which create the Credit Risk- Return Anomaly. The evidence shows that the Credit Risk-Return Anomaly exist only on developed market due to the market participants' ability to fully interpret an announcement on credit rating 
downgrades while a developing market lacks the ability, and hence does not experience Credit Risk-Return Anomaly.

So the key research question considered is if financial markets are strongly related in US, this relationship should hold in other markets as well, in particular for developed countries in Asia and Europe. While on the emerging markets, the arguments is that they have achieved stronger economic growth and successfully decoupled emerging markets from advanced economies. According to Dooley \& Hutchison (2009), emerging economies such as Asian and Latin American had grown to the point where they no longer depend on the US economy for growth. And due to this non-dependency, they have given stronger performance that outperforms the stock outside the United States especially. And the better performance also happens in equity sector, where the emerging countries with high credit risk has higher equities than the developed countries that have low credit risk. The result indicates that credit risk-return puzzle does not exist in emerging markets.

The representative countries in Asia consist of two developed countries and two developing countries. A direct comparison with the same method and period between these countries can give a broader understanding of the Credit Risk-Return Anomaly that takes hold in various conditions of different countries. Asian countries are said to be decoupled from the full effect of Global Financial Crisis, unlike United States, so the characteristics and magnitude of the credit risk-return relationship should be less prominent than the one in United States. With the developed Asian countries lies in between of its developed country characteristics and its Asian country characteristics, the observed credit risk-return relationship presented might be skewed a little towards emerging markets results. While for the developing country that is said decoupled from the developed economy should not have experienced the Credit Risk-Return Anomaly.

The study aims to provide evidence on the credit risk-return puzzle by investigating the empirical relationship between credit risk and stock returns in developed countries and developing countries in Asia. If the financial market is integrated then the credit risk-return puzzle should hold in the developed market. Developed market has a tendency to move toward a more financially integrated market so greater business cycle synchronization is expected, creating an environment where credit risk-return anomaly can exist. While in an emerging markets, the credit risk-return anomaly does not exist due to the economy outperformance because of decoupling, and the research is executed to find supporting proof of this lack of phenomenon in developing countries. According to 
Bissoondoyal-Bheenick \& Brooks (2015), the credit risk-return puzzle exists mainly due to the announcement of rating downgrades. So the purpose of this research is to proof that credit risk-return exist in developed.

\section{LITERATURE REVIEW}

\section{Credit Rating Agencies and the Importance}

Credit Rating Agencies are financial institutions that provide rating information of companies towards the market. According to the Comptroller of the Currency Administrator of National Banks (2012) guidance report on Rating Credit Risk for Federal Savings Associations (FSA), rating agencies are institutions that "provide independent credit ratings and analysis to keep the investment public informed about the credit condition of the obligors and instruments they rate." The report also stated that rating agencies are recognized and accepted as the issuer of credit risk measure in the form of credit ratings, and the top 3 internationally accepted rating agencies are Moody's, Standard \& Poor and Fitch. Calderoni, Colla, \& Gatti (2009) found that Credit Rating Agencies play a crucial role in financial markets due to their privileged access towards information that might not be available for public. It enables them to gain information advantage in comparison with individual investors. Lal \& Mitra (2011) stated that Credit Rating Agencies are also responsible for predicting changes in a company's financial and operational position before the investors are fully aware of these changes.

Some evidences of discrepancies in the way Credit Rating Agencies use related information for credit ratings assignment or credit rating changes. According to AbadRomero \& Robles-Fernandez (2007), credit rating agencies are faced with asymmetric loss functions where they would allocate more resources in their efforts of finding evidence on negative credit information. Their asymmetrical preferences are caused by the fact that the loss of reputation of giving the wrong valuation for credit rating upgrade (or too high of a credit rating) is more severe than the loss of reputation from giving a false credit rating downgrades, or too low of a credit rating. But Ramcharran \& Kim (2003) took the opposite point of view. Their research shows that credit rating agencies are hesitant to downgrade due to the fear of ruining business relationship with the related company. They consider is the fear of credit rating agencies towards contagion effect in the market, in which Pacheco (2012) also supported with his findings regarding contagion effect in bearish market.

Another research by Altman \& Rijken (2006) tries to provide insights on the throughthe- cycle methodology of Credit Rating Agencies, in which there are three contradicting and 
conflicting objectives that rating agencies have; rating stability, rating timeliness and defaultprediction performance. For Credit Rating Agencies, rating stability maintains their company reputation because rating reversals within a short period of time shows hesitation and confidence in the valuation they performed to assign long-term rating. So Altman \& Rijken (2006) found that Credit Rating Agencies divided rating decisions based on two parts, the permanent credit risk components and the prudent migration policy, that allows Credit Rating Agencies to avoid excessive rating reversals and still aiming for the acceptable level of timeliness. So Credit Rating Agencies focus exclusively on the permanent aspect of longterm ratings according to future prediction, and if rating changes must happen it is only a partial adjustments to the perceived level of credit risk components reflected in the long-term rating.

There are countless debates in the market regarding the actual value of information (in the form of credit ratings) provided by Credit Rating Agencies towards the market. One of the earliest research by Schweitzer, Szewczyk, \& Varma (1992), stated that there are two point of view regarding Credit Rating Agencies' capability in utilizing information in the market. The first view stated that rating agencies only have access towards publicly available information, which would not give them any informational advantage nor enable them to provide new information towards investors. The second point stated that rating changes do provide new information to the market because credit rating agencies can take the role of efficient processors of public information to obtain, process, and provide information at a lower cost, thus even though also based their ratings through publicly available information, it can still provide new information towards investors. Galil \& Soffer (2011) stated that due to the dual targeting of timeliness and stability of credit rating agencies they must have utilizes information that is not readily available for public to make their rating changes decision. This implies that the rating changes will convey new information for the capital market due to the impact of the information that is not disclosed to public.

Abad-Romero \& Robles-Fernandez (2007) stated that rating agencies based their rating assignment towards company on their solvency. It depends on the macroeconomic factors of the firms and their fundamentals so it can also be a measure of a firm's default probability. Ratings can give signal to the market about the firm's future prospects, with the expectation that stock price will based their movement on the credit ratings assigned. Linciano (2004) sees that rating agencies functions as the provider of summarized information at least towards stockholders and as a side effect, it can be a useful tool to discipline the market and to improve the corporate governance of the rated entities. His 
hypothesis is supported by Ferri \& Liu (2003) which stated that rating is necessary for potential creditors such as banks and institutional investors because potential creditors need an external measure of ratings as objective yardstick for the borrower's credit ability. But Ferri \& Liu (2003) stated this in relation towards credit ratings and also sovereign ratings, as their results show that the contribution of sovereign rating is high especially in developing countries due to the country ceiling effect, more so than the individual credit ratings. The contrasting point of view that stated credit ratings are not providing any informational value comes from Poon \& Chan (2008). They argued that credit ratings are not important for Chinese investors due to the lack of trust towards domestic credit rating agencies. Another point of view that questions the informational value provided by credit rating comes from Freitas \& Minardi (2013), which doubt the relevancy of the information provided by credit ratings to the market due to the through-the-cycle methodology of credit rating agencies. The delayed credit rating changes can cause the information related already infused in the stock price movement even before the announcement dates. But their result shows that rating changes in relation to downgrades are based on more intensive research by the credit rating agencies in comparison to upgrades, which can still give important informational value for rating downgrades but not significantly for rating upgrades.

The two contrasting point of view might be a result of different sample size used or the country's and method's characteristics. A further look into the sample used by the researchers bears interesting finding. The researchers that stated ratings have informational value used the sample of developed countries and the researchers that state credit ratings do not have informational value used the sample of developing countries. Schweitzer et al. (1992) used the data from United States as population, Linciano (2004) used Italian firms as their population, while Galil \& Soffer (2011) used CDS spreads from the global CDS markets. US, Spain and Italy are all developed countries. On the other side, Poon \& Chan (2008) used Chinese markets as their basis, Ferri \& Liu (2003) used 45 countries which consist mostly of developing countries, and Freitas \& Minardi (2013) focused their research on Latin American countries, which are all considered developing countries. It is important to note that the results from Ferri \& Liu (2003) that concluded sovereign ratings are more important than individual credit ratings of firms only applied to developing countries and not developed countries where they have no significantly high sovereign ratings. This makes the result of Ferri \& Liu (2003) that support the fact that individual credit ratings do not provide informational value only applied to developing countries. This provides a clear pattern that shows rating information is relevant in developed market while 
in developing markets the effect is not quite that relevant.

\section{Decoupling-Recoupling Hypothesis}

The different points of view in the importance of credit ratings shows a clear pattern of different reaction of developed and developing markets towards credit ratings. This difference between the reactions of developed market and developing market are possibly the proof of the "Decoupling-Recoupling Hypothesis" stated by Dooley \& Hutchison (2009). The research is done after the Global Financial Crisis in 2008 as the researchers are trying to evaluate the transmission of the crisis that started in the United States to the emerging markets, especially after 2008. There is one widely circulated view that stated emerging countries had taken some precautionary actions that would prevent them from absorbing the adverse shocks from financial crisis, which would render them a buffer from the effects of financial crisis, or in other words, the emerging markets would not be affected by the subprime crisis in the United States. The theory spurted from the fact that some emerging countries such as China have achieved stronger economic growth to a phase where they decoupled themselves from developed economies. There is empirical result provided by Dooley \& Hutchison (2009) which shows that Brazil and China outperforms the US market by quite a substantial margin. They concluded in the end that emerging markets were decoupled at first but then dramatically recoupled by early 2008 , and it is followed by most emerging markets at a relatively same time. The DecouplingRecoupling Hypothesis certainly provides a plausible explanation regarding the different reactions of developing markets and developed markets.

Wyrobek, Stańczyk, \& Zachara (2013) had rejected the Decoupling-Recoupling Hypothesis of Dooley \& Hutchison (2009) by stating that there wasn't any decoupling at the first place, that it was only a strong synchronization of GDP changes and a part of business cycle among different countries. Wyrobek et al. (2013) stated that the definition of decoupling itself generally means "the growing differences between business cycles and the growing difference in reaction to global shocks." They stated that even though the reaction comes at a later time, it is evident that all emerging countries are affected, which violates the definition of decoupling itself. From their result, they can conclude that business cycles all over the world are quite similar before crisis, and the countries are still following the same cycle even after crisis, which is most apparent in long and very short cycle. Wyrobek et al. (2013) reject the decoupling hypothesis because it is questionable for emerging countries to maintain their high sustainable growth if there is no recovery in economy of developed 
countries. But it is apparent from the results of Dooley \& Hutchison (2009) and Wyrobek et al. (2013) that there is a delay in the reaction of developing markets towards financial crisis. This delay, whether proof of decoupling hypothesis or not, might be the reason why there are different reactions from emerging markets and advanced markets towards credit ratings.

A plausible explanation comes from Avramov, Chordia, Jostova, \& Philipov (2012) regarding the reason behind the different reactions. Their results shows that the equity performance of high credit risk countries, which are emerging markets, outperforms the equity performance of low credit risk countries, which are the developed countries, by 57 basis points per month over the period of 1989 to 2009. But the differential is more pronounced at the later half of the period, and they stated, "The explanatory power of world credit risk factor is not spurious and significantly exceeds the explanatory power of the ratings." Avramov et al. (2012) also stated that country-level characteristics are important factors for cross-sectional country returns in non-integrated financial markets. Hence, there is a significant positive relationship between sovereign credit risk and the country equity returns. The result implied that emerging markets that are characterized with their higher credit risk earns higher returns due to the higher exposure towards world credit risk factor instead of their being of emerging market itself or because they have lower sovereign credit ratings. They also found that the positive pricing errors in emerging market would imply that there are negative pricing errors in developed market. This means that in the presence of world credit risk factor, pricing errors in developed market becomes insignificant. The result by Avramov et al. (2012) can shed some new point of view towards the debate of the existence of Asian decoupling phenomena, as it provides another alternative factor that can help explain the reason behind the positive relationship of credit risk and stock return in emerging markets and why does the result differ from the developed markets.

\section{Impact of Credit Rating Announcements on Stock Returns}

The credit risk-return anomaly existed in the US market and has been undergo observations and studies from many financial analysts. According to Campbell, Hilscher, \& Szilagyi (2008), this phenomenon started at 1981 when financially distressed stocks have low returns. The credit rating is considered as one measure of financial distress and used the default category or ratings to show that stocks with high risk of failures tend to have low average returns, especially in the small, illiquid stocks. The result of Dichev \& Piotroski (2001) is consistent with the result Campbell et al. (2008). They found out that low credit quality firms perform poorly after downgrades, which they attribute to market 
underreaction instead of rating announcements. Earlier research by Dichev (1998) on bankruptcy risk argued that if bankruptcy risk is systematic, then there should be a positive association between bankruptcy risk and realized returns. But he conclude that bankruptcy risk is not rewarded by higher returns, so this confirms that firms with high bankruptcy risk, which could represent firms with high credit risk, do earn substantially lower returns. Avramov et al. (2009) also assessed the relationship between credit risk and stock return and the results were that firms with low credit risk realize higher returns than firms with high credit risk. And it seems that this is unanticipated by the market, shown from the large negative earning surprises and analyst forecast revision. Avramov et al. (2009) also stated out another reason for the drop in the stock price, which is institutional selling. Financial institutions have fiduciary responsibilities in which they have a certain standard for the companies they may hold within their portfolios. If the downgrade decreases the company's rating towards a level that is no longer acceptable to the institutions, the number of that particular stock owned will be reduced.

One of the earliest research by Hand, Holthausen, \& Leftwich (1992) examined the impact of rating changes announcements on bonds and stock markets. A downgrade announcement resulted in negative returns of stocks on a stronger significant level while an upgrade announcements resulted in a positive returns of stock but on a lower significant level. Researches afterwards on United States market bears the same result of different significance level, such as the research of Dichev \& Piotroski (2001), while the researches by Avramov et al. (2009) and Friewald, Wagner, \& Zechner (2014) expand the research of Hand et al. (1992) by examining the further effect of credit rating downgrades towards performance of stock return. Where Dichev \& Piotroski (2001) concluded that the reason for the credit risk-return anomaly existed more due to the market underreaction than rating announcements itself, Bissoondoyal-Bheenick \& Brooks (2015) assigned much greater weight consideration into the impact of credit rating announcements on the changes of stock returns. More over, Bissoondoyal-Bheenick \& Brooks (2015) concluded that the impact of rating changes announcements on stock markets are more significantly shown on rating downgrades rather than a rating upgrades. They researched the effect of credit rating announcements in Australia and Japan market, and found out a consistent result with the US market that the movement of stock prices are positive during upgrade announcements and negative during downgrade announcements but the level of rising and dropping are different to such an extent where the drop in the prices are more significant.

Ariff \& Finn (1989) conducted a research on Singapore's stock return from 1980 to 
1985 to test the effect of announcements to the Asia-Pacific region where there are less wellresearched market. They concluded that there are statistically significant abnormal returns during the months up to and including the month of announcements. But compared to the more developed capital market, Singapore's trading volume and frequency at the time of the research is quite thin; as it is way lower than the trading frequency of a well-developed market, which leads to a less prominent effect of credit risk-return anomaly in Singapore market. The research of Linciano (2004) shows there are negative abnormal returns associated with rating downgrades, especially unanticipated downgrades that are not preceded by Credit Watch announcements. But for rating downgrades that is followed by Credit Watch announcements, the negative reaction is more significant for the Credit Watch announcement rather than the rating change announcement. Nonetheless the results show that a well-developed market have the credit risk-return anomaly.

From the point of view of developing market, Pirenaningtyas \& Eko (2013) had conducted the research in Indonesia with the result that Indonesia, even though a developing country, experience the credit risk-return phenomena. It is perceived that a developing market does not have the ability to fully interpret the information conveyed by rating changes announcements, but the result shows the opposite regarding the supposed lacking of the phenomena in Indonesian market. Another research by Zhou (2006) on six Asian exJapanese market, which also includes Indonesia, provides a comparable result. With the focus on emerging market that is characterized with their information asymmetry and low transparency, he shows that upgrades in Indonesia has no effect towards stock return while the result for downgrades shows a sign of information leakage associated within the pre- announcement period. There are still negative excess return on the after the period of announcement though, signifying an uncertainty in the market even though investors have received prior warning. Thus, the market anticipation neutralizes the announcement effect. Regardless, the direction of the stock price movement indicates that the credit risk-return anomaly do exist in Indonesian market. According to Poon \& Chan (2008) regarding China, given the emerging market environment of China and the fact that credit rating agencies are newly established, the agencies would use all available data as the basis for their valuation for rating assignment, hence they would also use company's data such as stock performance. This would create simultaneity in credit rating assignments and stock returns. Lal \& Mitra (2011) conducted similar researches on Indian market, and the result shows that there are significant negative abnormal returns after announcement of rating downgrades, while upgrades simply gives a positive but insignificant responses from the stock market. 
But according to Poornima et al. (2015) who also conducted their research in Indian market, shows that small cap companies are giving significant positive abnormal return in stock following a rating downgrade, and the market is not able to give positive return in the case of rating upgrade. But for mid-cap companies, more than half of the downgrades have negative significant impact before the announcement period, which means that downgrades have a very significant effect towards the market. The mixed reaction of the market differ according to the size of the company, so company size might be an important factor that determines the existence of credit risk-return anomaly.

There is another important factor that differentiates the effect of credit risk to stock returns in emerging markets, and according to Kaminsky \& Schmukler (2002), that factor is sovereign credit rating. Sovereign rating or country rating is more prominent in developing countries, as developing countries are perceived to have more risks due to the country's instability. And as it is a measure of the whole country's risks, usually a change in sovereign rating may affect all financial instruments' rating, and even stock market, accordingly due to the sovereign ceiling principle. Kaminsky \& Schmukler (2002) find that the relationship between credit risk and stock returns in general is negative, in which a downgrade (increase in credit risk) resulted in a lower stock return. The result is against the hypothesis of Asian economies' decoupling by Dooley \& Hutchison (2009). But the possible explanation for this inconsistency is that the decoupling phenomenon exists only just before the Global Financial Crisis period in 2008, in which the Asian markets are told to have exceptional growth that surpasses the growth of US economy. But overall, the results for the existence of credit risk- return anomaly in developing countries are still debatable due to inconsistency in the Decoupling-Recoupling Hypothesis, which it is only observable from 2008. The aforementioned theory by Avramov et al. (2012) stated that the higher return in emerging markets are not due to worse credit ratings but are more likely caused by their higher exposure to the world credit risk factor. This does not entirely rule out the theory that the anomaly does not exist in non-developed countries, but so far the results are not giving supportive evidence. Because the theory lies strongly on the DecouplingRecoupling Hypothesis of Dooley \& Hutchison (2009), adjustment to the model for emerging markets to world credit risk factor as stated by Avramov et al. (2012) might be needed. As it is previously stated before by Avramov et al. (2012), "Emerging markets earn higher returns not because they are classified as emerging or have worse credit rating. Rather they exhibit higher exposure to the world credit risk factor. 


\section{METHODS}

In the research, the stocks are not considered in a portfolio formation but rather consider whether the credit risk is priced on individual stocks. The original model was taken from the work of Bissoondoyal-Bheenick \& Brooks (2015). It will then be adjusted accordingly with the theory and hypothesis presented in the previous chapter to better capture the information needed and the phenomena. The original model from BissoondoyalBheenick \& Brooks (2015) is as presented below.

$R_{i t}=\alpha i+\beta 1 i$ Long-Term Rating $+\beta 2 i$ Long-Term Rating Change $+\beta 3 i$ Short-Term Rating $+\beta 4 i$ Short-Term

Rating Change $+\beta 5$ i Outlook $+\beta 8$ Firm Characteristics $(-2)+e i$

The regression model above becomes the foundational framework, as it is explanatory enough to capture the effect of credit rating changes on firms' abnormal return. But as the current research also focuses on determining the factor that differentiate the result for developed and developing countries, as well as the different results obtained by the existence of Credit Watch announcements, so another four independent variables are added to further expand the explanatory power of the model towards the variables wanted to be tested. The first added variable are the dummy variable used to identify whether the firm is a financial firm or an industrial firm; the second added variable is the country's sovereign rating, as it is a crucial factor for developing countries as stated by Ferri \& Liu (2003); the third variable added is the one used to detect Credit Watch, and the last variable is added to differentiate firms with credit ratings and firms without.

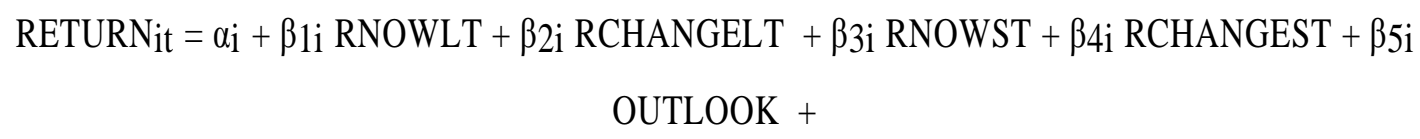


The method for the dataset is fixed effect model on unbalanced panel data. Individual intercepts are presented to control for individual-specific and time-invariant characteristics, called Fixed Effects. Baltagi, Bresson, \& Pirotte (2003) stated that the choice between Fixed Effect and Random Effect for panel data is an all or nothing choice, as Random Effect Model assumed exogeneity for all regressors and individual effects as Fixed Effect Model allows the assumption of endogeneity for all regressors and individual effects. As Hausman \& Taylor (1981) has proposed a model in between the two, as stated by Baltagi et al. (2003), "some of the regressors are correlated with the individual effects, as it uses both the between and within variation of the strictly exogenous variables as instruments". So Baltagi et al. (2003) suggest that the researcher consider a Hausman-Taylor model for the condition where some of the variables may be correlated with the individual effects. In this case, rhe dummy variable for Industry is time-invariant exogenous while the Country and Country Classification are time-invariant endogenous variables. In regard of this, the Hausman-Taylor Estimator is more appropriate for the dataset rather than Fixed Effect Regression Model.

This sort of research as a part of this investigation is hypothesis testing utilizing the descriptive approach. Descriptive approach is a research to portray the impact of independent variables on the dependent variable (Hartono, 2007). This study utilized a quantitative approach, since it depicts the relationship between research variables through hypothesis testing and data presented in the form of numbers calculated through statistical tests.

The population used as a part of this investigation is LGU in Probolinggo Municipal Government. The unit of analysis in this study is the officials involved in the preparation of budgets ranging from Head of LGU, Technical Executing Officer (PPTK) to Sub-Division Head of program compilers. The samples in this study using purposive sampling method with judgment sampling. It implies that researchers have certain contemplation in choosing the sample. The selected sample is limited to the people involved in preparing the budget so it is relied upon to provide information according to the actual situation in the field.

In accordance with the Minister of Home Affairs Regulation No. 21 of 2011 on the Second Amendment to the Regulation of the Minister of Home Affairs Number 13 of 2006, the task of preparing Workplan Budget and LGU Budget Execution Document is in the hands of the Head of LGU as the power of the budget user. During the implementation, head of LGU establishes a budget compilation team to arrange LGU Workplan Budget. Pursuant to the Decree issued by the Head of LGU, it can be seen that the officials involved in the 
preparation of the budget are the secretary or administration and Technical Executing Officer (PPTK). This study employed three groups of respondents in each LGU namely Head of LGU, Secretary or administrative affairs official and Technical Executing Officer (PPTK). The selection of these three groups of respondents has represented structural levels of officials ranging from echelon II to echelon IV officials. The total number of respondents is 120 people, each LGU consists of 3 people.

The sort of data utilized is the primary data, i.e data obtained directly from the original source. Primary data were collected by the researcher to answer the research question.

Data collection in this study was utilizing a questionnaire that is, an arrangement of inquiries that are set up to be submitted to the respondent. This questionnaire contains a rundown of structured questions addressed to respondents with a view to obtaining written information relating to budgetary participation, outer weights and LGU budgetary slack.

This research model derives from three equations to calculate the coefficient in testing the direct effect and moderation effects of the research model, the following is the equation:

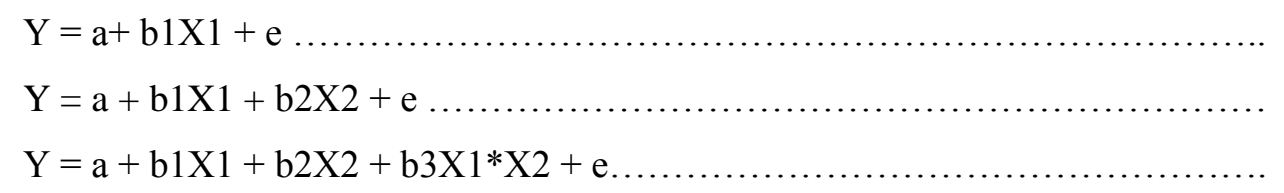

Remarks:

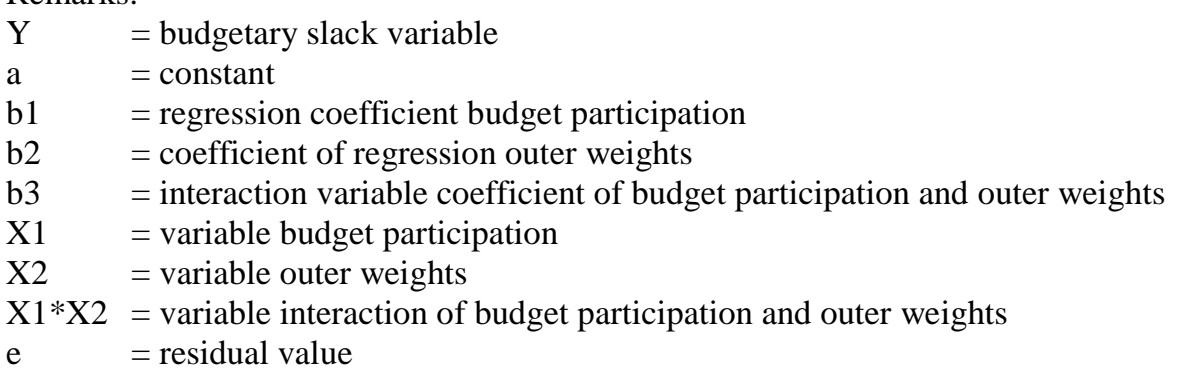

This study tested the hypothesis proposed using SPSS assistance. Hypothesis 1 was tested by simple regression, while hypothesis 2 using multiple regression. The initial step of regression is done to see the immediate influence of the independent variable to the dependent variable. The second step of the regression is done to include the moderation variable. The third step is to enter the interaction between the moderation variable and the independent variable.

\section{RESULTS}

The population of this research used four representative countries from Asia, consisting of two developing countries and two developed countries. The developed 
countries are represented by Singapore and Japan, while the developing countries are represented by China and Indonesia. The period spans from January 2001 to December 2015, consisting of monthly stock returns of individual companies, with the initial ratings for both individual credit ratings and country's sovereign rating, along with the changes in the individual credit ratings assigned to each one of the companies' bonds from the period 2001 to 2015. The rating changes are observed for both for long-term and the short-term. The Moody's credit ratings data for the companies of each country is taken from Bloomberg terminal as Moody's data provides the rating of company's recent bond issuance and also the historical matured ones, unlike Standard \& Poor's data that only listed current outstanding bonds. The superiority of the Moody's rating is shown through the work of Li et al. (2006) and Livingston, Wei, \& Zhou (2010). Li et al. (2006) managed to proof that the Japanese market trust Moody's more than S\&P. Livingston, Wei, \& Zhou (2010) compare the weights of importance for Moody's and S\&P credit ratings in the eyes of investors. The result shows that Moody's is most likely to give a more conservative rating, thus when the Moody's has the superior rating, investors requires lower yields than when $\mathrm{S} \& \mathrm{P}$ has the superior ratings, so there is advantages of relevance and completeness in using Moody's rating over Standard \& Poor's for the examination of long-run returns aside from the more conservative rating assignment.

Table 1 summarizes the total number of observations used for this analysis, including the observations from each country. As the methodology used is a regression model, every monthly data for firm characteristic acquired are needed to fill in the gap between rating changes, resulting in a huge amount of observations that have no actual rating changes.

Table 1. Summary of Number of Observations from the Countries

\begin{tabular}{|llclcl|}
\hline & Japan & Singapore & China & Indonesia & All \\
\hline Upgrades & 156 & 24 & 33 & 81 & 294 \\
\hline No Actions & 17786 & 2066 & 1834 & 3406 & 25092 \\
\hline Downgrades & 209 & 29 & 15 & 17 & 270 \\
\hline Total & 18151 & 2119 & 1882 & 3504 & $\mathbf{2 5 6 5 6}$ \\
\hline
\end{tabular}

Source: Processed by Authors, 2016

Table 2 describes the summary of the credit ratings from the observation as a whole, as well as the range of credit ratings from each of the observed countries. As it is seen on Table 2, the maximum long-term rating of developing countries is 22 (numerical value for Moody's Caa), while the maximum long-term rating of developed countries is 18 (the numerical value for Moody's B1). The figure shows that developing countries in general possess greater risk in terms of credit rating in comparison with developed countries, which 
is also shown from the minimum ratings. China's minimum rating of 5 (representing Moody's Aa3) and Indonesia's minimum rating of 10 (representing Moody's Baa1) are clearly higher than Japan's and Singapore's 1 (Moody's Aaa rating) and 2 (Moody's Aa1 rating) consecutively.

Table 2. Summary of Credit Rating's Range from the Countries

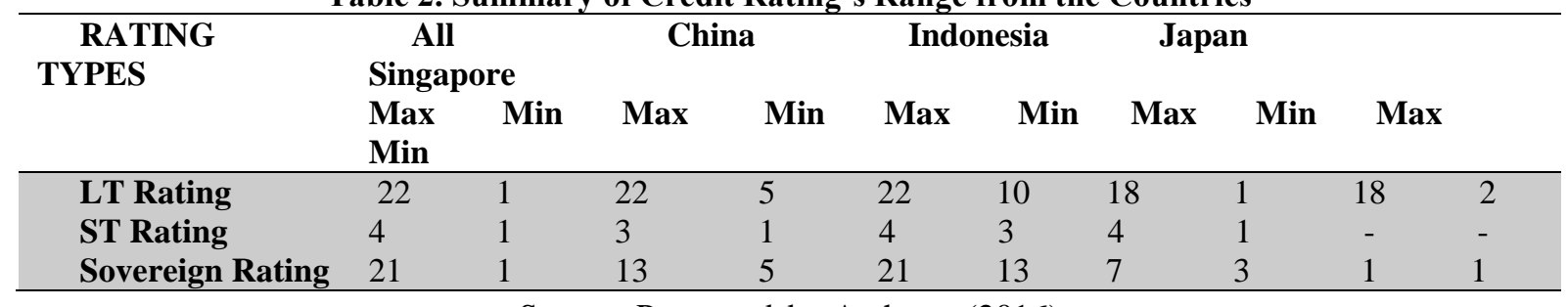

Source: Processed by Authors, (2016)

Another important point shown from Table 2 is that it does not fully support the theory of Ferri \& Liu (2003) that sovereign rating caps the individual rating of the companies, especially in less developed countries (LDCs). The evidence from China and Singapore support the theory, as the minimum value of credit rating does not exceed or at least at the same level of the minimum sovereign rating. But on the case of Indonesia and Japan, the data shows that the sovereign rating is exceeded by individual credit ratings, which means there are ratings from individual companies that performs better than the upper bound of the country itself. But upon further examination, researcher found that the minimum rating of 10 from Indonesia comes only from one company, which is Telekomunikasi Indonesia Persero Tbk. While two other companies that receive rate 11 are Bank Negara Indonesia Persero TBk and Bank Mandiri Persero Tbk. But both of the Baa2 ratings are only effective up until September 16th, 2009, right before the time of the Financial Crisis on 2008 full impact hit Indonesia and the rating got downgraded. The same for the case of Japan, the only firm with the rating of Aaa (exceeding Japan's highest sovereign rating of 3 ) is Toyota Motor Corp; with the effective period for the rating ended also right around the time the full effect of 2008 Financial Crisis hit Asia (February 6th, 2009). The other companies with an Aa1 rating (numerical value of 2) are Canon Inc, Denso Corporation, East Japan Railway Co, Nippon Telegraph \& Telephone Corporation and Tokyo Gas Co Limited. 
Table 3 Summary of Firm Characteristic per Country Classification

\begin{tabular}{lllcccc}
\hline \multicolumn{1}{c}{ Variables } & \multicolumn{2}{c}{ Developing Countries } & \multicolumn{2}{c}{ Developed Countries } & \multicolumn{2}{c}{ All Observations } \\
& Mean & Std. Dev & Mean & Std. Dev & Mean & Std. Dev \\
\hline Return & 0.012871 & 0.125713 & 0.006496 & 0.089715 & 0.0078341 & 0.098402 \\
MV. (in USD) & 118 bil. & $368 \mathrm{bil}$. & $40.9 \mathrm{bil}$. & $65.9 \mathrm{bil}$ & $57.1 \mathrm{bil}$ & $181 \mathrm{bil}$. \\
BV (in USD) & $9,55 \mathrm{bil}$. & $24.2 \mathrm{bil}$. & $9.84 \mathrm{bil}$. & $14.7 \mathrm{bil}$. & $9.78 \mathrm{bil}$. & $17.1 \mathrm{bil}$. \\
BV/MV & 0.220766 & 0.204927 & 0.44044 & 0.34323 & 0.39432 & 0.331503 \\
P/E Ratio & 19.1233 & 41.45442 & 30.44798 & 190.0428 & 27.96205 & 169.0771 \\
Turnover & 0.042913 & 0.05453 & 0.102736 & 0.087792 & 0.090178 & 0.08548 \\
\hline
\end{tabular}

Table 3, the firm characteristics divided only into 2 categories of developed countries (Japan and Singapore) and developing countries (China and Indonesia). The overall average return of the total observations is $0.7834 \%$ with $9.84 \%$ standard deviation. The return is slightly higher than the developed countries $0.6496 \%$ average but lower than the developing countries $1.287 \%$ of average return. This result shows that in the least, firms in developing countries do possess greater return due to the greater risk China and Indonesia bear as developing countries. The Market Value from each company differs in accordance with the currency of the country it is in, so in order to create a comparable value for all countries, the Market Value is defined in US dollars by using the monthly historical rates of foreign exchange from USForex Group for the corresponding date. The summary shows that the overall mean of Market Value is US\$ 57.1 billions, with the average of market value in developing countries around US\$ 118 billions and the average market value in developed countries is around US\$ 40.9 billions. But the clear factor that differentiates the size of the firms between the ones in developing and in developed countries is shown from the average Book Value (also in US dollars). It is shown that the average BV for firms in developing countries are US\$ 9.55 billions, while the minimum BV for firms developed countries is US\$ 9.84 billions. The value indicates that firms in developed countries are more established and bigger in size in comparison with the one in developing countries, as book value measure the internal performance of the company without the interference of stock market performances. The possible reason for the greater Market Value in developing countries can be seen from the average Book-to-Market ratio (BV/MV). The BV/MV ratio of the developing countries is 0.220766 , lower than developed countries 0.44044 book-to-market ratio, which signifies that the stocks of the firms in developing countries are more overvalued than the one in developed countries, causing greater market value while book value signifies otherwise. This indicates that the effect of stock overvalued performances is clearly shown on market values, biasing the supposedly clear indicator of firm size. The average P/E Ratio is higher for developed countries, a 30.448 compared to 
the 19.123 P/E Ratio for developing countries. This indicates that generally investors are anticipating higher growth and better performances for the companies in developed countries. The result from the Shares Turnover, a 0.04291 from the developing countries against a 0.10274 from developed countries, shows that the stock of the firms in developed countries are traded more frequently than the stock of the firms in developing countries.

Table 4. Hausman-Taylor Estimation for All Observations

\begin{tabular}{|c|c|c|c|c|}
\hline \multirow[b]{2}{*}{ RETURN } & \multicolumn{2}{|c|}{ Without Bootstrap } & \multicolumn{2}{|c|}{ With Bootsrap } \\
\hline & Coeffcients & Std. Error & Coeffcients & Std. Error \\
\hline \multicolumn{5}{|c|}{ Time-Variant Exegenous } \\
\hline RNOWLT & $-0.0008256 * * *$ & 0.0002912 & $-0.0009309 * * *$ & 0.0002555 \\
\hline RCHANGELT & $0.0009285^{*}$ & 0.0005009 & $0.0010769 * *$ & 0.0004642 \\
\hline RNOWST & -0.0031406 & 0.0027792 & -0.003617 & 0.0035127 \\
\hline RCHANGEST & 0.0118528 & 0.0078263 & 0.0111553 & 0.00111557 \\
\hline RATENOW & 0.0089704 & 0.0135947 & 0.0067159 & 0.0138455 \\
\hline RATEPREV & -0.0192488 & 0.0140815 & -0.0190802 & 0.038966 \\
\hline $\mathrm{CW}$ & -0.0040862 & 0.0027534 & -0.003662 & 0.0025267 \\
\hline OUTLOOK & -0.0022422 & 0.001467 & -0.0020877 & 0.0018322 \\
\hline RSOVEREIGN & 0.0005721 & 0.0004185 & 0.000909 & 0.0003914 \\
\hline CUMRETURN & $0.1527345^{* * *}$ & 0.0021962 & $0.1567654 * * *$ & 0.0016701 \\
\hline LOGMV & $-0.0394238 * * *$ & 0.0040971 & $-0.0455298 * * *$ & 0.006587 \\
\hline BVMV & $0.0641941 * * *$ & 0.0048832 & $0.0695846 * * *$ & 0.0093571 \\
\hline PE & $-0.0001699 * * *$ & 0.0000259 & $-0.0317483 * * *$ & 0.0000368 \\
\hline TURNOVER & $-0.0323855 * * *$ & 0.114706 & $-0.0128784 * *$ & 0.0140403 \\
\hline \multicolumn{5}{|c|}{ Time-Invariant Exogenous } \\
\hline INDUSTRY & $0.0435385^{*}$ & 0.0223514 & $0.069745 * * *$ & 0.0141631 \\
\hline \multicolumn{5}{|c|}{ Time-Invariant Endogenous } \\
\hline COUNTRY & $-0.1102499 *$ & 0.057252 & $-0.151071 * *$ & 0.0515602 \\
\hline CLASS & $0.9878415 *$ & 0.5384636 & $1.385565 * *$ & 0.4771579 \\
\hline Constant & $0.5644845 * * *$ & 0.1420182 & $0.7395216 * * *$ & 0.1536471 \\
\hline
\end{tabular}

Source: Processed by Author, 2016

The significance level of each coefficient is represented by the symbol *, which consist of $10 \%$ significance $(*), 5 \%$ significance $(* *)$ and $1 \%$ significance $(* * *)$. The variables that are classified as the time-variant exogenous variables are long-term credit rating (RNOWLT), long-term credit rating changes (RCHANGELT), short-term credit rating (RNOWST), short-term credit rating changes (RCHANGEST), dummy for current and previous ratings (RATENOW and RATEPREV), credit watch (CW), rating outlook (OUTLOOK), country's sovereign rating (RSOVEREIGN), 6-months cumulative return (CUMRETURN), log of market value (LOGMV), book-to-market ratio 
(BVMV), P/E Ratio (PE) and shares turnover (TURNOVER). Firm characteristics data is winsorized with the tail value set to $5 \%$ percentile of the whole data to reduce the number of extreme value observations. The time-invariant exogenous variable is the dummy for firm's industry (INDUSTRY) due to the same classification for the firm regardless of the period of observations. And the time-invariant endogenous variables are country classification (CLASS) and the country (COUNTRY) itself, as they can affect the dependent variable, the firm's monthly return (RETURN), with economic policy or different law and regulations.

Table 4 show the regression, which is variables used for the Hausman-Taylor Estimation are divided into time-variant and time-invariant variable. As Hausman-Taylor Estimation would need endogenous variables to be able to run properly, the variables used for classifying different groups of country is utilized. The time-invariant endogenous variables are country classification (CLASS) and the country (COUNTRY) itself, as they can affect the dependent variable, the firm's monthly return (RETURN). As the characteristics between developed and developing countries differ, the variable CLASS is classified into time-invariant endogenous variables.

The result with bootstrapped standard errors shows that the long-term rating is affectingthe monthly return in a negative direction (-0.08256\% with $1 \%$ significance), which supports the negative relationship between credit rating and expected stock return. This is in accordance with the theory of Bissoondoyal-Bheenick \& Brooks (2015) regarding the existence of the credit risk-return anomaly, as higher credit ratings (higher risk) will give lower return instead. Although the result from the full observations does not clearly show whether the developing or developed countries is more clearly contributing towards this anomaly, the regression run with sub-samples will. But the result from the long-term rating changes is the exact opposite from the long-term credit rating. An increase of the positive direction of credit rating changes (signifying a credit rating downgrade) will increase the expected return of the corresponding firm by $0.09285 \%$ with $5 \%$ significance level. This positive coefficient shows that within the one-month period of credit rating downgrades, the expected return increases. Short-term rating and short-term rating changes are not significant in regard to stock returns even though the direction of the movement follows the one of longterm ratings, which signifies that short-term rating changes does not concern investors as long-term ratings are deemed a better representative for firm's condition and prospect for the future. Country's sovereign rating is affecting stock return in a positive direction by $0.05721 \%$, indicating that the as the country's sovereign rating increase, investor requires 
higher return to compensate for the risk. As country's sovereign rating usually determines the condition of a country, it can be alternative factor used to see the required return investor needs in developed and developing countries.

Table 4, all of the variables used are statistically significant at least at 5\% significance level. Brennan et al. (1998) research on these non-risk characteristics provides insight on how these factors provide explanatory power relative to the stock returns. The 6-months cumulative returns variable is positively significant at 0.1527345 points. As Brennan et al. (1998) stated in his work, the addition of lagged return variables "should improve the efficiency of the estimates of the coefficients of the other variables". For the firm size, it confirms the result of previous studies in which generally firms with lower market value tend to earn higher return than firms with higher market value. It is confirmed by the negative coefficient of market value, which is -0.0394238 points. Brennan et al. (1998) stated that the addition of trading volume within his research as additional firm characteristics made the firm size variable significant as Shares Turnover takes trading volume into account. For the book-to-market ratio, the increase in market-to- book ratio is followed with the increase in stock return by 0.0541941 points. The positive relationship exist due to the condition where a high book-to-market ratio defines the undervaluation level of stock performance, as stated by Griffin \& Lemmon (2002), while a low book-to-market ratio are considered overpriced. For the P/E Ratio and Shares Turnover, both have negative coefficients (at -0.0001699 and -0.0323855 respectively). Higher P/E Ratio would give lower stock returns in the long-term, as it is very hard to sustain a high P/E Ratio over longterm horizon. While shares turnover, serving as a proxy of liquidity, can serve as sentiment index for investors according to Baker \& Wurgler (2006). Thus, it supports the result that high shares turnover forecasts low market returns. The dummy variable for industry is also highly significant (by 0.0435385 points), indicating that the stock return for financial firms is to be higher by $4.35 \%$ than for non-financial firms.

\section{DISCUSSION}

The regression is run numerous times for different classification, the first one exclude upgrade announcements, the second one exclude downgrade announcements, while the third one is run with the exclusion of both rating upgrade and downgrades (see Appendix). The purpose is to clearly see which rating actions are contributing to the movement of coefficients regarding to stock returns with regards to the specific characteristics of developing and developed countries. It is shown from the coefficient of long-term 
credit rating for the whole observations that the coefficient for each rating actions does not differs much. The coefficients shown are $-0.0773 \%$ (Coefficient D) for rating actions excluding downgrades and $-0.08324 \%$ (Coefficient $\mathrm{G}$ ) for rating actions excluding upgrades. So as credit ratings become higher (possess greater risk), the stock return decreases in response. This is in line with the proposed theory of credit risk-return anomaly of Dichev \& Piotroski (2001) and Bissoondoyal-Bheenick \& Brooks (2015), which highlights the negative relationship between credit risk and stock market returns. Even though the result long-term credit ratings is according to the proposed theory, unfortunately the result for the long-term credit rating change is significant but for the opposite direction. As it is seen from the coefficients of for the whole observations, both the coefficients for rating actions excluding downgrade and rating actions excluding upgrade, $0.08257 \%$ (Coefficient D) and $0.091 \%$ (Coefficient G) respectively, are positive on $10 \%$ significance level. While the result differs, the presented value of increase in return is greater in magnitude for credit rating downgrades (rating actions excluding upgrades). The result is higher by $0.00843 \%$ in comparison with the rating upgrade, which can give reasonable comparison between the magnitudes of the effect of rating actions towards stock returns.

Appendix also shows the result of the regressions for developing and developed countries. As before, the coefficients for the variables have the same direction as the regression for the overall observations (with all rating actions included). The coefficient for long-term credit ratings in developing countries is -0.0015631 (Coefficient B), while it is 0.0002109 (Coefficient C) for developed countries. The difference from the two values shows that the decrease in return for developing countries is higher in magnitude in comparison with the decrease in value for developed countries.

As developing countries are benchmarked from their sovereign ratings to have greater risks, the decrease in return is also bigger in magnitude to properly react to the higher increase in risk. The coefficients for long-term changes in credit rating for both classifications are positive at 0.0017271 (Coefficient B) for developing countries and 0.0004898 (Coefficient C) for developed countries. A positive coefficient means that a credit rating downgrade is responded with an increase in return, opposing the theory of credit riskreturn anomaly. Put the direction aside, the coefficient for long-term credit rating changes for the developed countries is less "positive" than the coefficients for developing countries. Even though both signs are positive, it is clear that the magnitude of return increase for developed countries is not as big for developing countries. A closer look on the coefficients on the whole observations for long-term credit rating downgrades, 0.000910 (Coefficient 
G), and long- term credit rating upgrades, 0.0008257 (Coefficient D), shows that the movement of credit rating downgrades provoke a greater effect for stock return by $0.00843 \%$. The result shows that a credit rating downgrade is followed by stronger stock return reactions. Aside from the whole observations, the results for developing countries regarding the magnitude of credit rating downgrade are also in line with the fact, as the result for developing market shows that the effect credit rating downgrade is greater by $0.14331 \%$. For the results of developed market, it is in fact the other way around, as the magnitude of credit rating downgrade is less (more negative) by $0.01542 \%$. This shows that credit rating downgrade in developing market is actually giving out higher return while credit rating downgrade in developed market is giving a more negative return, well aligned with the theory of Bissoondoyal-Bheenick \& Brooks (2015) on how credit risk-return puzzle will give out more negative return on downgrades for well developed countries.

Beside that, Appendix also classifies the rating actions for the observations of developing countries (Coefficient E, H and K). The long-term credit rating's coefficient is negative as it is for the other observations. The negative relationship between the longterm rating and the stock return shows that the credit risk return anomaly also exist in developing market, although the positive direction for credit rating changes signifies otherwise. The previous research by Bissoondoyal-Bheenick \& Brooks (2015) shows that both the coefficients for long-term credit rating and long-term rating changes are negative, which support fully the theory of credit risk-return anomaly. But another research by Goh \& Ederington (1993) provides an insight on how the stock return reacts towards a credit rating downgrade. They categorized the reason behind rating downgrades into two groups; one is due to the deterioration in the firm's financial prospect while the other one is due to the increase in leverage of the firm. According to Goh \& Ederington (1993), the deterioration in firm's financial prospect has negative implication towards stock performance, but the increase in leverage gives positive implication for stockholders as it reflects the past known leverage increases. The conclusion drawn for this is that rating changes cannot be treated as homogenous, as different causes might provide different reactions. In this case, the positive reaction towards credit rating downgrade is visible for all observations, indicating that the main reason behind the downgrade is an increase of firm's leverage instead of financial deterioration.

The comparison for the coefficient of long-term credit rating changes for developing countries between upgrade and downgrade shows that upgrades boost up return by $0.17698 \%$ (Coefficient E), while credit rating downgrades boost up return by $0.17518 \%$ 
(Coefficient H). This result clearly shows that the developing market is reacting towards downgrade by an increase in return instead of a decrease. This supports the hypothesis that the developing market does not experience credit risk-return anomaly, as there are really small difference on the response for upgrade and downgrade. On the other hand, the result of the developed market signifies otherwise. In developed market, a credit rating upgrade gives an increase in stock return by $0.05475 \%$ (Coefficient F), while a credit rating downgrade gives $0.03933 \%$ (Coefficient I) increase in stock return, which shows that they are reacting more negatively towards credit rating downgrades rather than upgrades. The result certainly is on line with the credit risk-return puzzle.

The interesting point from Appendix (Coefficient E, $\mathrm{H}$ and $\mathrm{K}$ ) is that the short-term credit ratings are significant for developing countries, and the short-term rating changes are even more significant than the long-term rating changes. A downgrade from a short-term rating would induced a significantly positive stock return reaction, which shows that the developing countries market are more perceptive towards short-term changes rather than long-term. This might be due to the fact that developing market does not possess the ability to fully interpret the information conveyed by credit ratings, as it is shown from the fact that the market is more concerned towards short-term ratings instead of the corresponding longterm ratings. The developed countries result on Appendix (Coefficient F, I and L) classifies the rating actions for the observations of developed countries, and as it from previous results, the direction for the long-term rating and long-term rating changes persist. But both longterm rating and long-term rating changes are not considered significant for developed market, which is puzzling because developed market is viewed to be able to fully interpret the information conveyed from credit ratings. Aside from the insignificance of the rating changes, the direction of the coefficient from long-term credit rating signifies the presence of credit risk-return anomaly while the long-term rating changes does not, from the positive signs on rating changes. Even though the developed market reacted more negatively for credit rating downgrades, the direction of stock return is still positive. But the reasons for downgrade are important in determining the market reaction towards a credit rating downgrade, as explained in the work of Goh \& Ederington (1993). The difference in the magnitude of reaction towards long-term rating and their changes can be seen as a signal that even though the direction of the movement is the same, but the difference magnitude shows how strong the market reacts towards specific changes.

Table 5. Hausman-Taylor Estimation Based on Industry Classification 


\begin{tabular}{|c|c|c|c|c|}
\hline \multirow{2}{*}{ RETURN } & \multicolumn{2}{|c|}{ Financial Firms } & \multicolumn{2}{|c|}{ Non-Financial Firms } \\
\hline & Observed Coef. & $\mathrm{z}$ & Observed Coef. & $\mathrm{z}$ \\
\hline \multicolumn{5}{|c|}{ Time-Variant Exogenous } \\
\hline RNOWLT & -0.0007045 & $-2.9^{* * *}$ & 0.0000577 & 0.12 \\
\hline RCHANGELT & 0.0002837 & 0.46 & 0.0010838 & $1.7^{*}$ \\
\hline RNOWST & -0.0007952 & -0.4 & -0.0013215 & -0.2 \\
\hline RCHANGEST & 0.0032078 & 0.28 & 0.0236886 & 1.27 \\
\hline RATENOW & 0.0084343 & 0.41 & 0.019972 & 1.07 \\
\hline RATEPREV & -0.0152468 & -0.76 & -0.0178649 & -0.83 \\
\hline $\mathrm{CW}$ & -0.0078537 & $-2.18^{* *}$ & 0.0003294 & 0.07 \\
\hline OUTLOOK & -0.0000533 & -0.03 & -0.0070788 & $-3.62^{* * *}$ \\
\hline RSOVEREIGN & 0.0003039 & 0.72 & 0.0029027 & $3.93^{* * *}$ \\
\hline CUMRETURN & 0.151451 & $87.2^{* * *}$ & 0.155074 & $55.26^{* * *}$ \\
\hline LOGMV & -0.0239511 & $-3.88^{* * *}$ & -0.0534065 & $-4.08^{* * *}$ \\
\hline BVMV & 0.0661024 & $5.03^{* * *}$ & 0.0549598 & $3.6 * * *$ \\
\hline PE & -0.0002021 & $-4.42 * * *$ & -0.0001341 & $-3.33 * * *$ \\
\hline TURNOVER & -0.0586592 & $-3.15 * * *$ & 0.0023016 & 0.12 \\
\hline \multicolumn{5}{|c|}{ Time-Invariant Exogenous } \\
\hline INDUSTRY & 0.0275199 & $4.16^{* * *}$ & 0.037086 & $2.27 * *$ \\
\hline \multicolumn{5}{|c|}{ Time-Invariant Endogenous } \\
\hline COUNTRY & 0.0622009 & $2.81^{* * *}$ & -0.1215093 & $-2.99 * * *$ \\
\hline CLASS & -0.5973593 & $-2.89^{* * *}$ & - & - \\
\hline cons & 0.0268548 & 0.88 & 2.840496 & $3.08^{* * *}$ \\
\hline Observations & \multicolumn{2}{|c|}{16367} & \multicolumn{2}{|c|}{9289} \\
\hline$F=0.0000$ & \multicolumn{2}{|c|}{ Wald Chi2 $=15,749.83$} & \multicolumn{2}{|c|}{ Wald Chi2 $=9,612.87$} \\
\hline
\end{tabular}

Source: Processed by researcher (2016)

The significance level of each coefficient is represented by the symbol *, which consist of $10^{\circ} \%$ significance $(*), 5 \%$ significance $(* *)$ and $1 \%$ significance $(* * *)$. The variables that are classified as the time-variant exogenous variables are long-term credit rating (RNOWLT), long-term credit rating changes (RCHANGELT), short-term credit rating (RNOWST), short-term credit rating changes (RCHANGEST), dummy for current and previous ratings (RATENOW and RATEPREV), credit watch (CW), rating outlook (OUTLOOK), country's sovereign rating (RSOVEREIGN), 6-months cumulative return (CUMRETURN), log of market value (LOGMV), book-to-market ratio (BVMV), P/E Ratio (PE) and shares turnover (TURNOVER). Firm characteristics data is winsorized with the tail value set to $5 \%$ percentile of the whole data to reduce the number of extreme value observations. The time-invariant exogenous variable is the dummy for firm's industry (INDUSTRY) due to the same classification for the firm regardless of the period of observations. And the time-invariant endogenous variables are country classification (CLASS) and the country (COUNTRY) itself, as they can affect the dependent variable, the firm's monthly return (RETURN), with economic policy or different law and regulations.

Meanwhile Table 5 differentiates the observations by industry classification, divided into financial firms and non-financial firms. The result shows that long-term rating for financial firms has a negative coefficient (-0.0007045 points), which indicate the presence of the credit risk-return anomaly. As for the non-financial firms, the long-term rating has a positive coefficient ( 0.0000577 points). Putting the different direction of the movement aside, the magnitude of the effect for long-term rating in stronger for financial firms rather than for non-financial firms. Linciano (2004) also divided the observations into financial and non-financial firms, and the result shows that long-term rating is only significant for financial firms, supporting the result here. It is also shown from the coefficient of the longterm rating changes that the movement of return in the case of rating downgrade is positive, 0.0002837 for financial firms and 0.0010838 for non-financial firms. The value and the 
significance level indicate that the movement of stock prices is greater for credit changes in non-financial firms. As for the stronger magnitude of effect for credit rating downgrades, it is also supported by the research of Schweitzer et al. (1992). According to Schweitzer et al. (1992), due to the regulation that covers capital structure of financial firms, the security of financial firms is more predictable than the security of industrial firms. Financial firms are operating in a highly regulated environment that demands the maintenance of safety and soundness the primary concerns, so close monitor from regulatory institutions enables them to identify financial organization's distressed conditions prior to the failure. This predictability in the movement of financial firms caused the effect of rating changes is not as great in magnitude, as it is easier for market participants to read and predict the movement of the stock in comparison with the non- financial firms.

\section{CONCLUSION}

The research assesses the credit risk-return anomaly in developed market and developing market using representative countries of Indonesia, China, Japan and Singapore to establish whether the these markets face the similar credit risk-return anomaly as it holds in the United States market. The objective is to compare the results of the developing and the developed market, whether the magnitude of the anomaly presence would be the same for both. The empirical findings indicate that the credit risk-return anomaly exist in both developed and developing markets, but on the long-term credit ratings alone. The negative relationship between credit rating and stock return is observed in several situations and they persist. The interesting point is that for the actual credit rating changes, the result shows that positive relationship is present for all conditions. This result differs from the previous literatures in the light that there might be different reasons behind the action of rating downgrades. As when the rating downgrades takes place due to the increase in leverage instead of financial deterioration, previous literature shows that it is responded with an increase in stock return instead of decreasing stock return. This shed a new light in the point where not all action of credit rating downgrades should be treated the same.

There is evidence that downgrade invoke greater response in stock return rather than credit rating upgrade, indicating that credit rating downgrades provide more informational value towards the market participants. For the different reaction of developing and developed market, the empirical results provide an insight where rating actions are invoking greater responses in developing markets rather than in developed markets, and also stronger for financial firms rather than non-financial firms. A contribution from the effect of 
sovereign ratings in developing markets is also present, as it serves as caps for individual firm's credit ratings in developing market, but is not significant in developed market. All in all, the research provides an empirical evidence on the presence of credit risk-return anomaly in both developed and developing market, even though rating changes does not provide evidence towards the anomaly due to the different reason behind the credit rating downgrades. The research also equally establish that credit ratings from credit rating agency, especially Moody's, provide a good measure of financial performances that is reflected in the stock market returns behavior.

\section{REFERENCES}

Abad-Romero, P., \& Robles-Fernandez, M. D. (2007). Bond rating changes and stock returns: Evidence from the Spanish stock market. Spanish Economic Review, 9(2), 79-103.

Altman, E. I., \& Rijken, H. A. (2006). A Point-in-Time Perspective on Through-theCycle ratings. Financial Analysts Journal, 62(1), 54-70.

Ariff, M., \& Finn, F. J. (1989). Announcement Effects And Market Efficiency In A Thin Market: An Empirical Application To The Singapore Equity Market. Asia Pacific Journal of Management, 6(2), 243-265.

Avramov, D., Chordia, T., Jostova, G., \& Philipov, A. (2009). Credit Ratings and The Cross-Section of Stock Returns. The Journal of Financial Markets, 12(3), 469499.

Avramov, D., Chordia, T., Jostova, G., \& Philipov, A. (2012). The World Price of Credit Risk. The Review of Asset Pricing Studies, 2(2), 112-152.

Baker, M., \& Wurgler, J. (2006). Investor Sentiment and the Cross-Section of Stock Returns. The Journal of Finance, 61(4), 1645-1680.

Baltagi, B. H., Bresson, G., \& Pirotte, A. (2003). Fixed Effects, Random Effects or Hausman- Taylor? A Rretest Estimator. Economic Letters, 79, 361-369.

Barron, M. J., Clare, A. J., \& Thomas, S. H. (1997). The Effect of Bond Rating Changes and New Ratings on UK Stock Returns. Journal of Business Finance and Accounting, 24(3), 497-509.

Bissoondoyal-Bheenick, E., \& Brooks, R. (2015). The credit risk-return puzzle: Impact of credit rating announcements in Australia and Japan. Pacific Basin Finance Journal, 35, 37-55.

Brennan, M. J., Chordia, T., \& Subrahmanyam, A. (1998). Alternative factor specifications, security characteristics, and the cross-section of expected stock 
returns. Journal of Financial Economics, 49(3), 345-373.

Calderoni, F., Colla, P., \& Gatti, S. (2009). Rating Changes across Europe. Universita Bocconi. Campbell, J. Y., Hilscher, J., \& Szilagyi, J. (2008). In Search of Distress Risk. The Journal of Finance, 63(6), 2899-2939.

Comptroller of the Currency Administrator of National Banks. (2012). Rating Credit Risk. Multi-asset Risk Modeling.

Dichev, I. D. (1998). Is the Risk of Bankruptcy a Systematic Risk? Journal of Finance, 53(3), 1131-1147.

Dichev, I. D., \& Piotroski, J. D. (2001). The Long-Run Stock Returns Following Bond Ratings Changes. Journal of Finance, 56(1), 173-203.

Dooley, M., \& Hutchison, M. (2009). Transmission of the US Subprime Crisis to Emerging Markets: Evidence on the Decoupling-Recoupling Hypothesis. Journal of International Money and Finance, 28(8), 1331-1349.

Ferri, G., \& Liu, L.-G. (2003). How Do Global Credit-Rating Agencies Rate Firms from Developing Countries? Asian Economic Papers, 2(3), 30-56.

Freitas, A. de P. N., \& Minardi, A. M. A. F. (2013). The impact of credit rating changes in Latin American stock markets. Brazilian Administration Review, 10(4), 439-461.

Friewald, N., Wagner, C., \& Zechner, J. (2014). The Cross-Section of Credit Risk Premia and Equity Returns. Journal of Finance, 69(6), 2419-2469.

Galil, K., \& Soffer, G. (2011). Good news, bad news and rating announcements: An empirical investigation. Journal of Banking and Finance, 35(11), 3101-3119.

Goh, J. C., \& Ederington, L. H. (1993). Is a Bond Rating Downgrade Bad News, Good News, or No News for Stockholders? Journal of Finance, 48(5), 2001-2008.

Griffin, J. M., \& Lemmon, M. L. (2002). Book-to-market equity, distress risk, and stock returns. The Journal of Finance, 57(5), 2317-2336.

Hand, J. R. M., Holthausen, R. W., \& Leftwich, R. W. (1992). The Effect of Bond Rating Agency Announcements on Bond and Stock Prices. The Journal of Finance, 47(2), 733-752.

Hausman, J. A., \& Taylor, W. E. (1981). Panel Data and Unobservable Individual Effects Author: Jerry A. Hausman and William E. Taylor. Econometrica, 49(6), 1377-1398.

Kaminsky, G., \& Schmukler, S. L. (2002). Emerging Market Instability: Do Sovereign Ratings Affect Country Risk and Stock Returns? The World Bank Economic Review, 16(2), 171-195. 
Lal, J., \& Mitra, M. (2011). Effect of Bond Rating on Share Prices: A Study of Select Indian Companies. The Journal of Business Perspective, 15(3), 231-238.

Linciano, N. (2004). The Reaction of Stock Prices to Rating Changes. Quaderni Di Finanza, Studi E Ricerche, 57.

Livingston, M., Wei, J. D., \& Zhou, L. (2010). Moody's and S\&P Ratings: Are They Equivalent? Conservative Ratings and Split Rated Bond Yields. Journal of Money, Credit and Banking, 42(7), 1267-1293.

Pacheco, L. (2012). Moody's Credit Ratings And Stock Market Performance Of Portuguese Rated Firms. Journal of Advanced Studies in Finance, 3(1), 66-83.

Pirenaningtyas, F. H., \& Eko, U. P. (2013). Bond Rating Change Announcement and the Effect on Stock and Bond Return. International Journal of Administrative Science \& Organizations, 20(2), 57-64.

Poon, W. P. H., \& Chan, K. C. (2008). The Effects of Credit Ratings on Stock Returns in China. Chinese Economy, 41(2), 34-55.

Poornima, B. G., Umesh, N. P., \& Reddy, Y. V. (2015). The Impact of Changes in Credit Ratings on Stock Returns. IUP Journal of Financial Risk Management, 12(3), $52-67$.

Ramcharran, H., \& Kim, I. W. (2003). Evaluating the Impact of Credit Risk on Emerging Market Stock Returns. American Business Review, 21(2), 81-87.

Schweitzer, R., Szewczyk, S. H., \& Varma, R. (1992). Bond rating agencies and their role in bank market discipline. Journal of Financial Services Research, 6(3), 249-263.

Wyrobek, J., Stańczyk, Z., \& Zachara, M. (2013). Decoupling Hypothesis and the Financial Crisis. Financial Assets and Investing, 4(3), 25-40.

Zhou, C. (2006). Information Value of Credit Ratings in Asia Ex-Japan Markets. Singapore Management University. 


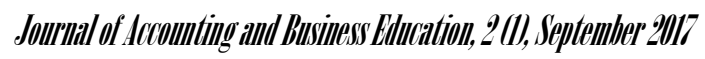

All Ratiog Aetian taeleded

Exclade Ruting Dewngrades

Exdude Ratinz Lipgrades

Exelude Ruting Ae

\begin{tabular}{|c|c|c|c|c|c|c|c|c|c|c|}
\hline All & Developing & Developed & All & Developing & Developed & All & Deweloping & Developod & All & Developing \\
\hline Cost. (A) & Coef. (B) & $\operatorname{Cot}($ (C) & $\operatorname{Cost}(D)$ & $\operatorname{Cosf}(\mathrm{E})$ & $\cos ($ (F) & $\operatorname{Cost}(G)$ & Coet. (A) & $\operatorname{Coc}($ (I) & $\operatorname{Coef}(1)$ & $\operatorname{Cocf}(K)$ \\
\hline $5644845 \cdots$ & $-0.657109 \cdots$ & $2.768169 \cdots$ & 0.4742292 & $-0.6259363 \cdots$ & $2976044 \cdots$ & $0.667977 \times$ & $-0.6527617 \cdots$ & $2.901021 \cdots$ & $0.5878779 * 7$ & $-0.6211074 \cdots$ \\
\hline \multicolumn{11}{|c|}{ Time-Variant Frogenoes } \\
\hline, $000 \times 256 * \cdots$ & $-0.0015631 \cdots$ & -0.0002109 & $-0.000773 \cdots$ & $-0.00016369 * *$ & -0.0001305 & $-0.000 \times 324 \cdots$ & $-0.0015903 \cdots$ & -0.0001767 & $-0.00078 \times 1 \cdots$ & $-0.0016229 \cdots$ \\
\hline $1.0009285 *$ & 0.0017271 & 0.0004898 & $0.0008257^{*}$ & 0.0017698 & 0.0005475 & $0.00091^{*}$ & 0.0017518 & 0.0003933 & 0.0008135 & 0.0017953 \\
\hline-0.0031406 & $-0.012617 \cdots$ & 0.001357 & -0.0028282 & $-0.0128136^{\circ *}$ & 0.0015412 & -0.0090795 & $-0.0127035 \%$ & 0.0014963 & -0.0028398 & $-0.0128995 *$ \\
\hline 0.0118528 & $0.031458^{*}$ & 0.009106 & 0.011559 & $0.0316475 \cdots$ & 0.0021763 & 0.0118148 & $0.0315649^{*}$ & 0.0089155 & 0.0115452 & $0.0317573 * *$ \\
\hline 0.0089704 & -0.0122951 & 0.0806875 & 0.0084133 & -0.0104342 & 0.0224772 & 0.0089345 & -0.012262 & 0.0201675 & 0.008199 & -0.0103944 \\
\hline-0.0192488 & -0.0075175 & -0.0210424 & -0.077424 & -0.010571 & -0.0215367 & -0.019145 & -0.0078075 & -0.0199233 & -0.0176109 & -0.0108732 \\
\hline 0.0040862 & -0.0030561 & $-0.0055504^{*}$ & -0.0043825 & -0.0023492 & -0.0040645 & -0.003842 & -0.0030444 & $-0.0057838^{\circ}$ & -0.0041079 & -0.0023373 \\
\hline-0.0022422 & -0.0023011 & $-0.0025323 *$ & -0.0020344 & -0.0056447 & $-0.002329 *$ & $-0.0030101 *$ & -0.0023111 & $-0.0022005 *$ & $-0.0028308 * *$ & 0.0056592 \\
\hline 0.0005721 & -0.0002992 & $0.0024967 * *$ & 0.0006983 & -0.0000783 & $0.0024964 * \cdots$ & 0.0005779 & $-0.00028 \times 3$ & $0.0024764 \cdots$ & 0.0006674 & -0.0000658 \\
\hline $.1527345 \cdots$ & $0.149831 \cdots$ & $0.1558903 *$. & $0.1525493 \ldots$ & $0.1490417 * \ldots$ & $0.156157+\cdots$ & $0.1525493 \ldots$ & $0.1495056 \cdots$ & a.1556485*.. & $0.1522821 \cdots$ & $0.1490135 \ldots$ \\
\hline $10094238 \cdots$ & $-0.035195 \ldots$ & $-0.0552096 \%$ & $-0.0356732 \cdots$ & $-0.0349133 \cdots$ & $-0.0596555 * \ldots$ & $-0.0604872+\ldots$ & $-0.0350367 \ldots$ & $-0.0546645 \cdots$ & $-0.0377406 \cdots$ & $-0.0347296 \%$ \\
\hline $06941941 \ldots$ & a.osoli322. & $0.0583641 \ldots$ & $0.0658562 \cdots$ & 0.0603091 * & $0.05752 k \cdots$ & $0.0653432 \cdots$ & $0.0501789 * *$ & $0.0590392 \ldots$ & $0.0667491 \ldots$ & $0.0603719 \times$. \\
\hline $10001699 * \ldots$ & $0.0008238 \ldots$ & $-0.0001178 \ldots$ & -0.0001670. & $-0.0005513 \cdots$ & $-0.000133 \cdots$ & $-0.0001705 * \ldots$ & $0.0008231 \cdots$ & $-0.0001165 \cdots$ & $-0.0001684 \cdots$ & $-0.0008507 * \ldots$ \\
\hline $0.0323855 *$ & $0.132901 \cdots$ & -0.0105645 & $-0.03277 \mathrm{~s}^{*}$ & $-0.1512471 \cdots$ & -0.0112791 & $-0.0381466 * \cdots$ & $-0.1327301 \%$ & -0.0116129 & $-0.0387143 *$ & $-0.1510597 \cdots$ \\
\hline \multicolumn{11}{|c|}{ Time-Invariant Exogeaous } \\
\hline $0435385 \cdots$ & $0.0584023 \cdots$ & $0.0259836 \cdots$ & 0.0620229 & $0.060931 \cdots$ & $0.02662 \cdots$ & $0.0481855 \cdots$ & $0.0581368 \cdots$ & $0.0268772 \cdots$ & $0.0431807 \ldots$ & $0.0606353 \ldots$ \\
\hline \multicolumn{11}{|c|}{ Time-Invariaat Eadogenous } \\
\hline $102499 * *$ & $0.079539 \ldots$ & $-0.1172124 \cdots$ & -0.860101 & $0.0764559 \cdots$ & $-0.1258637 \ldots \ldots$ & $-0.1437283 \cdots$ & $0.079131 \ldots$ & $-0.1237598 \ldots$ & $0.1211324^{*}$ & $0.0759922 \ldots$ \\
\hline $878415=$ & . & . & $0.7658578 \ldots$ & . & . & $1.291463 *$ & - & . & $1.084613^{*}$ & - \\
\hline $7,665.63$ & $2,728.06$ & $15,661,42$ & 19.532 .28 & $2,570.17$ & $24,824,2$ & $12,625,47$ & $2,122.81$ & 19.217 .68 & $17,198.21$ & 5063.69 \\
\hline 0.0000 & 0.0000 & 0.0000 & 0.0000 & 0.0000 & 0.0000 & 0.0000 & 0.0000 & 0.0000 & 0.0000 & 0.0000 \\
\hline 25656 & 5386 & 20270 & 25386 & 5272 & 20090 & 25362 & 5394 & 20032 & 25092 & 5240 \\
\hline
\end{tabular}

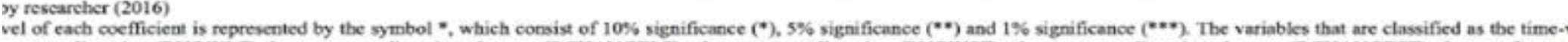
term credit rating (RNOWLT), long-terna credit rating changes (RCHANGEIT), short-term credit rating (RNOWST), short-term credit rating changes (RCHANGEST), dummy fos cur N and RATEPREV), credit watch (CW), reting outlook (OUTLOOK), country's sovereign rating (RSOVEREIGN), 6-months cumulative returm (CUMRETURN), log of market value (L

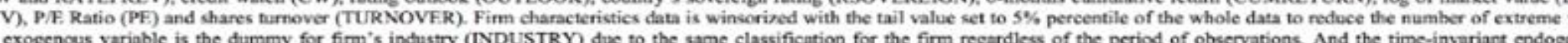
to (CLASS) and the country (COUNTRY) itself, as they can affect the dependent variable, the firm's monthly return (RETURN), with economic policy or different law and regulations. 